\title{
Böwö Wangowalu: Perlukah Ditransformasi?
}

\author{
Bözö Wangowalu: Should it be transformed? \\ Intan Tri Kristiani Gulo ${ }^{\bowtie}$, Tuhoni Telaumbanua ${ }^{1}$ \\ 1Sekolah Tinggi Teologi Banua Niha Keriso Protestan Sundermann
}

\section{ARTICLE INFO}

Submitted: May 28, 2021

Review: October 23, 2021

Accepted: December 4, 2021

Published: December 29, 2021

\section{KEYWORDS}

böwö wangowalu, dowry, marriage, Nias, transformation

\section{CORRESPONDENCE}

Phone:

E-mail: intan1997gulo@gmail.com

\begin{abstract}
A B S T R A C T
Böwö (dowry) in Nias culture is very important in holding weddings. Böwö has a profound meaning: kindness, love, goodness, and gift (in Nias language, known as masi-masi). Often the purpose of böwö falls into böli gana'a (referring to the bride). As a result of this shift in meaning, some problems can lead to poverty, family disharmony, and reluctance to marry Nias women. From this problem, the research aims to find out the extent of theological understanding, practice, and the impact of the high nominal value of böwö. In addition, the authors also examine the role of parents in building the proper perspective on böwö. The method used to conduct the research is interviews and observation. The people of Nias say that the meaning of böwö has shifted; the main thing for parents in determining böwö is not masimasi but a measure of the level of education of women. Therefore, for the sake of a harmonious and prosperous life, a transformation is needed in the understanding, system, and procedure of böwö in Nias. To realize this transformation requires the involvement of many parties, especially the family, traditional elders, the church, and the government. Nias custom as an identity remains sustainable and brings blessings in people's lives.
\end{abstract}

\begin{abstract}
A B S TRAK
Böwö (maskawin) dalam adat istiadat Nias sangat penting dalam melangsungkan pesta pernikahan. Böwö memiliki arti yang sangat dalam yaitu cinta kasih (masi-masi). Seringkali makna böwö luruh menjadi böli gana'a (merujuk kepada pengantin perempuan). Akibat dari pergeseran makna ini, maka terjadi persoalan yang dapat bermuara pada kemiskinan, keluarga tidak harmonis, dan keengganan menikah dengan perempuan Nias. Dari masalah yang terjadi ini, maka tujuan penelitian ialah mencari tahu sejauh mana pemahaman teologis, praktek, dan juga dampak dari tingginya nilai nominal böwö. Selain itu, penulis juga meneliti peran orang tua dalam membangun prespektif yang benar terhadap böwö. Metode yang digunakan untuk melakukan penelitian yaitu wawancara dan observasi. Masyarakat Nias mengatakan bahwa makna dari pada böwö telah mengalami pergeseran; hal utama bagi orang tua dalam menentukan böwö bukanlah kasih (masi-masi) tetapi ukuran tingkat pendidikan perempuan. Oleh karena itu, demi kehidupan yang harmoni, sejahtera, maka dibutuhkan transformasi pada pemahaman, sistem, dan tata cara böwö di Nias. Untuk mewujudkan transformasi ini, dibutuhkan keterlibatan banyak pihak, terutama keluarga, penatua adat, gereja dan pemerintah, sehingga adat Nias sebagai identitas tetap lestari, dan mendatangkan berkat dalam kehidupan masyarakat.
\end{abstract}

Kata kunci: böwö wangowalu, jujuran, maskawin, perkawinan di Nias, transformasi 


\section{PENDAHULUAN}

$\boldsymbol{B}_{\text {i }}^{\text {i }}$ öwö atau maskawin, juga dikenal dengan istilah mahar dan/atau jujuran adalah adat istiadat yang penting pada pesta pernikahan di Nias. Dalam adat istiadat perkawinan di Nias, böwö merupakan istilah yang merujuk pada segala kebaikan (budi baik) yang dilakukan oleh seseorang kepada orang lain tanpa pamrih. ${ }^{123}$ Ketika orang Nias menerima kebaikan tanpa pamrih dari orang lain, mereka mengatakan: "fefu böwö si sökhi si no öbe'e khöma tebai masulöni" (segala kebaikan/budi baik yang telah engkau berikan kepada kami tak dapat kami balaskan). Ini menunjukkan bahwa böwö sinonim dengan kata 'masi-masi'. ${ }^{4}$ Menurut Hans Daeng dalam Mendrofa, mahar (böwö) adalah keseluruhan prosedur penyerahan yang oleh adat telah ditetapkan oleh pihak laki-laki kepada pihak perempuan sesuai dengan lapisan dan kedudukan sosial masing-masing sebelum seorang laki-laki secara resmi mengambil seorang perempuan. ${ }^{5}$

Böwö dalam perkawinan adat Nias menunjukkan (a) status sosial masyarakat Nias; (b) pengakuan, penghormatan, dan penghargaan terhadap martabat wanita; (c) simbol penghargaan dan penghormatan (dalam kontesk budaya); dan (d) sebagai alat untuk mencegah terjadinya perceraian (Zebua dalam Gowasa, 2019: 22). ${ }^{6}$

Sebutan böwö di daerah-daerah lain memiliki perbedaan dengan adat Nias, dalam tradisi adat Banjar sebutan böwö adalah jujuran yang ditandai dengan sejumlah uang yang diberikan dan yang sudah disepakati oleh keluarga laki-laki dan keluarga perempuan. Uang jujuran itu tidak diperuntukan kepada

1 Samina T. Mendrofa, Mas Kawin (Bowo) Pada Suku Bangsa Nias (Medan: USU Press, 2007), 72.

2 Jinner Sidauruk and Lenny Verawaty Siregar, Peranan Mahar (Bowo) Dalam Tatacara Melangsungkan Perkawinan Menurut Hukum Adat Nias (Medan, 2011), 8.

3 Fransiskus Andi Luanta Gowasa, "Perkawinan Semarga Menurut Hukum Adat Nias (Studi Di Kabupaten Nias Selatan Dan Kota Gunungsitoli)" (Universitas Sumatera Utara, 2019), 21.

${ }^{4}$ H. S. Zebua, Kamus Sederhana Bahasa Daerah Nias Indonesia (Gunungsitoli, Nias, 1996), 33.

5 Mendrofa, Mas Kawin (Bowo) Pada Suku Bangsa Nias, 72.

${ }^{6}$ Gowasa, "Perkawinan Semarga Menurut Hukum Adat Nias (Studi Di Kabupaten Nias Selatan Dan Kota Gunungsitoli)," 22-23. perempuan tetapi uang itu digunakan untuk kebutuhkan pada saat pesta pernikahan berlangsung. ${ }^{7}$ Sedangkan dalam tradisi adat Batak böwö sebagai sinamot yang dimaknai sebagai tuhor (uang jujur). Sinamot ini juga disebut sebagai alat beli, karena pada hakikatnya sinamot merupakan suatu transaksi dari pihak laki-laki kepada pihak perempuan, sehingga sinamot diartikan sebagai biaya atau harga yang diperlukan untuk menciptakan sukacita bersama dalam mewujudkan suatu pesta pernikahan. ${ }^{8}$ Dari prespektif ini dapat dilihat dengan jelas bahwa böwö dalam adat istiadat Nias berbeda dengan jujuran yang dalam tradisi adat Banjar maupun Batak.

Secara etimologis böwö adalah hadiah yang diberikan secara cuma-cuma kepada anak dan juga kepada orang lain; misalnya pada saat melangsungkan pernikahan ada sebagian orang diberikan sumange (penghargaan) dalam bentuk makanan (daging babi dan sirih). ${ }^{9}$ Namun seiring dengan perkembangan zaman, böwö yang tadinya memiliki arti yang sangat baik dan Kristiani itu mengalami pergeseran makna dan nilai. Dalam tradisi perkawinan di Nias, böwö merupakan unsur penting di dalam melangsungkan pernikahan. Sahnya sebuah perkawinan apabila böwö telah diberikan oleh pihak pengantin laki-laki kepada pihak pengantin perempuan, dalam bentuk sejumlah uang, babi, beras, emas dan perak.

Pada dasarnya, penetapan böwö pernikahan dalam masyarakat Nias ditentukan oleh status (bosi) adat. Penetapan adat ini, sudah mengalami pergeseran. Arus globalisasi memasuki nilai-nilai kebudayaan lokal, tanpa terkecuali, termasuk pergeseran dalam menetapkan böwö perkawinan. ${ }^{10}$ Böwö tidak lagi

7 Dwi Condro Wulan, "Pandangan Hukum Islam Terhadap Tradisi Jujuran Dalam Prosesi Perkawinan Adat Banjar Di Kelurahan Sungai Malang Kecamatan Amuntai Tengah Kabupaten Hulu Sungai Utara" (Universitas Islam Indonesia Yogyakarta, 2018), 12-17.

8 Maria Grace Delima, "Kedudukan Sinamot (Uang Jujur) Dalam Perkawinan Menurut Hukum Adat Batak Toba" (Universitas Indonesia, 2014).

${ }^{9}$ W. Gulo, ed., "Injil Dan Budaya Nias," in Seminar

Lokakarya Perjumpaan Injil Dan Budaya Nias (Gunungsitoli: Panitia Semiloka, 2004), 53.

10 Petrus Meiman Syukur Tafonao, “Pergeseran Penetapan Bowo Perkawinan Atas Status Sosial Di Kabupaten Nias Barat" (Universitas Sumatera Utara, 2016), 1, https://repositori.usu.ac.id/handle/1234567 $89 / 9746$. 
dipahami sebagai pemberian cuma-cuma orang tua kepada anaknya tetapi diidentikkan dengan böli niha yang sebenarnya bertolak belakang. Böli niha dimaknai sebagai imbalan atau harga, yang artinya jual beli tawar-menawar manusia. ${ }^{11}$

Pastor Romanus Daeli dalam Gulo (2015) mengatakan böwö adalah masi-masi (bukti kasih). Pendapat Romanus ini juga dibenarkan oleh salah satu tokoh terpelajar yang bernama Heseli Zebua, yang mengatakan böwö adalah masi-masi, (pemberian/derma kepada seseorang yang miskin tanpa menuntut balasan). ${ }^{12}$ Sejalan dengan Romanus dan Haseli, Simon Waruwu mengatakan bahwa böwö merupakan "masi-masi, nibe'e si'oroi dödö tenga ni'andrö ba tenga siso sulö" (bukti kasih, pemberian dari hati, bukan diminta dan tanpa menuntut balas). Simon juga mengatakan bahwa böwö memiliki nilai etis: "fasumangeta ba li ba amuata si sökhi" (sikap saling menghormati melalui kata dan perbuatan) dan memiliki nilai kemurahan hati bukan nilai material (babi, uang, emas dan emas). ${ }^{13}$

Böwö dalam tradisi Nias terdiri dari lima jenis yaitu: kefe (uang kertas), bawi (babi), böra (beras), firö (uang perak), dan ana'a (emas). Kelima jenis böwö ini menunjukkan lambang kekayaan seseorang dalam melaksanakan sebuah pernikahan [Wawancara, 23/4].

Pada dasarnya penentuan tingkatan böwö dalam perkawinan masyarakat Nias didasarkan pada status sosial seseorang, disebut bosi. Status sosial (bosi) dalam masyarakat makin tinggi, maka makin tinggi pula böwö yang harus diterimanya [Wawancara, 23/4]. Ada lima tingkatan bosi dalam masyarakat Nias, yaitu: tingkatan yang ketujuh (bosi sifitu), untuk orang kebanyakan. Kedua, tingkatan yang kedelapan (bosi siwalu), untuk kepala atau ketua adat di kampung. Ketiga, tingkatan yang kesembilan (bosi sisiwa) untuk sanuhe ba nöri. Keempat, tingkatan yang ke sepuluh (bosi sifulu) untuk tuhenöri (kepala negeri yang membawahi beberapa desa atau kampung) keturunan raja samönö tuhabadanö yang membuat ketetapan adat dan peraturan serta pernah melaksanakan pesta besar (owasa). Kelima, tingkatan yang kedua belas (bosi sifelendrua) [Wawancara, 23/4].

11 Ibid., 2.

12 Pontius Gulo, Böwö Dalam Perkawinan Adat Öri Moro'ö Nias Barat (Bandung: Unpar Press, 2015).

13 Ibid.
Tingkatan bosi sangat menentukan dalam adat pernikahan di Pulau Nias karena melalui pernikahan, status sosial dalam masyarakat otomatis bergeser lebih tinggi karena sudah berkeluarga.

Salah satu desa yang masih memelihara tradisi meminta böwö yang tinggi ialah Desa Sisarahili I, Kecamatan Mandrehe, Kabupaten Nias Barat. Warga desa memahami böwö sebagai salah satu hal penting saat proses kelangsungan pesta pernikahan, karena böwö menjadi salah satu penentu terlaksana atau tidak terlaksananya pesta pernikahan. Ada banyak kaum muda yang memang enggan mencari jodoh (mamaigi niha) di Sisarahili I karena nilai nominal böwö yang diminta relatif tinggi. Nilai nominal böwö selalu dilihat dari status sosial dan tingkat pendidikan perempuan. Jika anaknya sudah berpendidikan dan/atau memiliki status sosial yang baik, maka böwö yang diminta berbeda dengan perempuan yang belum berpendidikan dan/atau status sosial.

Tingginya nilai nominal böwö tersebut memiliki dampak dalam keluarga baru. Sesuai hasil penelitian penulis dampak dari besarnya nilai nominal bözö yang diminta dapat menjadi penyebab kemiskinan keluarga yang baru dibentuk karena utang yang besar pada saat pesta pernikahan itu. Kemiskinan dapat menyebabkan keluarga yang baru dibentuk tidak harmonis. Selain itu, ada banyak perempuan yang enggan dinikahi oleh para pemuda dari daerah lain akibat nilai nominal böwö yang diminta kepada orang tua pihak lakilaki terlalu tinggi. Akibat nilai nominal böwö yang tinggi, laki-laki dan perempuan mencari jalan yang mudah ditempuh yaitu dengan kawin lari (moloi). Selain itu juga ada juga yang menikah dengan orang yang berbeda agama karena böwö yang tinggi. Orang tua perempuan memberikan nilai nominal böwö yang tinggi karena mereka menghitung semua biaya yang dikeluarkan pada saat anaknya sekolah, tingkat pendidikan perempuan anaknya, dan jumlah sumange (penghargaan) yang kelak diberikan. Sumange diberikan kepada paman pengantin perempuan (sibaya) dan juga undangan. Acara mamuli nukha/femanga gahe (mengembalikan baju/memakan kaki babi yang sudah dimasak) merupakan satu tahapan yang wajib dilakukan setelah pesta pernikahan selesai. Ada atau tidaknya baju yang dikembalikan pada acara 
tersebut, menentukan bentuk atau jenis nilai nominal jujuran yang harus diberikan oleh keluarga pihak laki-laki.

Pernikahan bagi Ono Niha merupakan ritus terbesar dibandingkan kelahiran dan kematian. ${ }^{14}$ Pernikahan adat Nias memiliki filosofi. Laki-laki sering dihubungkan dengan "pihak bawah" (soroi tou) atau hilir sungai, sedangkan perempuan dihubungkan dengan "pihak atas" (ngöfi) artinya bahwa untuk meminang seorang perempuan, laki-laki butuh daya juang mencapai hulu untuk meraih atau mendapatkan tanömö niha yakni perempuan yang kelak menjadi istrinya. Tantangan yang sering dihadapi oleh laki-laki ialah persiapan pengadaan berbagai jenis jujuran yang disyaratkan untuk diserahkan kepada keluarga pihak perempun. ${ }^{15}$

Praktek böwö yang berlangsung sekarang tidak sehakikat dengan makna yang sebenarnya. Ono Niha pada awalnya memahami bahwa böwö memiliki arti yang sangat baik dan Kristiani. Mereka juga mengatakan bahwa böwö adalah masi-masi (bukti kasih). Böwö diwujudkan dalam kasih yang tidak mengharapkan balasan. Jika keluarga si A memiliki makanan lalu mereka membagikannya kepada keluarga si B maka orang itu akan dinamai niha si sökhi böwö. Artinya böwö diberikan secara cuma-cuma kepada orang lain yang didasari oleh kasih tanpa memilih-milih orang. ${ }^{16}$

Ada beberapa perkembangan wujud dari böwö walöwa: ${ }^{17}$

- Sebelum Ono Niha mengenal emas dan perak, maka böwö ini diwujudkan dalam bentuk kerja. Jika laki-laki mau menikahi seorang perempuan maka ia harus bekerja terlebih dahulu kepada orang tua perempuan yang ingin ia nikahi (ono yomo). Kemudian diwujudkan juga dari bentuk ngaso'e wakhe dan rozi mbawi yang ditakar dengan afore.

14 Tuhoni Telaumbanua and Uwe Hummel, Salib Dan Adu: Studi Sejarah Dan Sosial-Budaya Tentang Perjumpaan Kekristenan Dan Kebudayaan Asli Di Nias Dan Pulau-Pulau Batu Indonesia (1865-1965) (Jakarta: BPK Gunung Mulia, 2015), 356.

15 Ibid.

16 Pontius Gulo, Böwö Dalam Perkawinan Adat Öri Moro'ö Nias Barat, 80.

17 Tuhoni Telaumbanua, Upacara Dan Böwö Wangowalu Ba Nono Niha, Perlu Reformasi? (Gunungsitoli, 2020).
- Pada saat Ono Niha menjalin komunikasi dengan pihak luar (Barus, Johor, Aceh, dan juga Minang) dan mengenal yang namanya emas maka Ono Niha juga memakai emas dalam menentukan jujuran yang dinamakan köla, batu (emas), aya (aya nina, aya gawe aya zalawa).

- Sejak Indonesia secara khusus Nias mengenal mata uang firö (gulden) maka, firö (gulden) termasuk dalam unsur böwö wangowalu.

- Pada saat Indonesia mengenal mata uang rupiah maka Ono Niha jua menggunakan rupiah dalam menentukan böwö walöwa.

Para sosiolog juga mengatakan bahwa böwö pada hakikatnya tidak salah namun telah mengalami perubahan makna yang sesungguhnya. Para misionaris berusaha untuk menyederhanakan penetuan nilai nominal böwö karena bagi mereka nilai nominal yang tinggi menimbulkan masalah yang besar dalam keluarga yang dibentuk. Böwö sering kali menimbulkan diskusi yang serius sejak konferensi para misionaris sejak tahun 1908 namun tidak dimasukkan ke dalam amakhoita (ketentuan yang sudah di putuskan oleh orang tua dulu). Misionaris melihat bahwa jujuran merupakan salah satu hal yang berbahaya dalam kehidupan Ono Niha, namun mereka sangat hati-hati dalam memasukkannya dalam amakhoita zatua.18 Jika tidak penuh dengan kehati-hatian maka akan menimbulkan ketegangan dalam masyarakat. Untuk mengatasi ketengan tersebut maka langkah yang diambil ialah mendukung keputusan yang diambil oleh pemerintah kolonial dengan membatasi tingginya jumlah maskawin. Misionaris meminta pelayan gereja (pendeta pribumi, guru jemaat dan juga satua niha keriso) untuk menjadi contoh dengan jalan tidak menuntut jujuran yang bisa memberatkan hidup anak mereka ke depan. Namun hal ini ditolak oleh pelayan gereja karena mereka takut dikucilkan oleh masyarakat. Mereka juga mengatakan bahwa baik para misionaris maupun kolonial Belanda tidak dapat mengubah aturan böwö dalam masyarakat Nias sebab yang bisa melakukan itu hanyalah Salawa (kepala desa) dan juga Tuhenöri (tokoh adat)

18 Telaumbanua and Hummel, Salib Dan Adu: Studi Sejarah Dan Sosial-Budaya Tentang Perjumpaan Kekristenan Dan Kebudayaan Asli Di Nias Dan Pulau-Pulau Batu Indonesia (1865-1965). 
dalam upacara fondrakö. ${ }^{19}$ Pernyataan ini juga didukung oleh salah seorang tokoh adat yang ada pada salah satu Desa di Kecamatan Mandrehe.

Seiring berjalannya waktu böwö menjadi masalah karena perubahan-perubahan yang menimbulkan kemiskinan. Pada awalnya makna dari pada böwö sangatlah baik bahkan sangat dijunjung tinggi, namun makna yang sesungguhnya tentang böwö sudah bergeser, saat ini besar-kecilnya nilai nominal böwö ditentukan oleh pendidikan anak dan jabatan orang tua.

Bertolak dari uraian di atas, penelitian ini bertujuan untuk mencari tahu sejauh mana pemahaman teologis, praktek, dan juga dampak dari tingginya nilai nominal böwö. Selain itu, penulis juga meneliti peran orang tua dalam membangun prespektif yang benar terhadap böwö.

\section{METODE}

Pendekatan yang digunakan dalam penelitian ini ialah pendekatan kualitatif dengan metode sosio-historis (perpustakaan dan penelitian lapangan). Penelitian ini akan menggali informasi lisan dan juga tertulis tentang böwö wangowalu.

Penelitian dilaksanakan di Desa Sisarahili-I merupakan salah satu desa di wilayah Kecamatan Mandrehe, Kabupaten Nias Barat. Desa ini termasuk dalam wilayah dataran tinggi/penggunungan dan juga berbatasan dengan Desa Zuzundrao, Kecamatan Mandrehe, Kabupaten Nias Barat dan Desa Hilimaöga, Kecamatan Mandrehe, Kabupaten Nias Barat. Warga Desa Sisarahili-I berjumlah 1.823 jiwa: laki-laki 868, perempuan 955 dari 432 KK [Sumber: Dokumen Desa, n.d., 19-20].

Sumber data yang diperoleh pada saat melakukan penelitian ialah bersumber dari warga Desa Sisarahili-I 10 orang orang tua (Manahati Gulo, Dasar Hati Gulo, Atoföna Gulo, Suara Gulo, Hadi Soslima Gulo, Fama Gulo, Sinema Gulo, Soli Gulo, Anugrah Gulo, Ama Salina Gulo); 3 orang tokoh adat (Fajar Gulo, Fati'aro Gulo, Tema Gulo,); 1 orang kepala desa (Temanasokhi Gulo); 5 orang pemuda (Misi Gulo, Piant Gulo, Wilson Gulo, Samiati Gulo, Epipanias Gulo); 5 orang perempuan (Surya

19 Ibid.
Gulo, Reformasi Daeli, Saniati Waruwu, Salina Waruwu, Penerus Gulo); dua orang pendeta (Wa'aszaro Gulo, Fenieli Gulo); dan 1 orang katekis (Serius Gulo). Teknik yang dilakukan untuk mengumpulkan data ialah dengan melakukan wawancara dan observasi.

Setelah mengumpulkan data-data baik melalui wawancara dan observasi di lapangan, maka data yang terkumpul dibandingkan dengan penelitian kepustakaan yang juga berbicara tentang böwö. Setelah melalukan perbandingan dari penelitian lapangan maupun penelitian kepustakaan, maka dilakukan analisis secara umum terhadap temuan penelitian.

\section{HASIL}

Berdasarkan hasil wawancara yang sudah dilakukan dan juga membandingkannya dengan tulisan Ledawa Gulo (Alm) dikatakan bahwa böwö sudah ditargetkan dalam tekhemböwö. Kata tekhemböwö ini berasal dari dua kata yang tidak bisa dipisahkan yaitu tekhe yang berarti hasil keputusan yang sudah ditetapkan secara bersama-sama, dan böwö (ni'oböwögö) yang artinya keikhlasan hati seseorang dalam memberikan sesuatu atau dalam membantu orang lain. Dari pengertian dua kata ini maka dapat disimpulkan bahwa tekhemböwö adalah keputusan yang ditetapkan secara bersama dengan ke ikhlasan hati atau tanpa paksaan [Gulo \& Gulo, Wawancara, 22/4].

Böwö bukan harga dalam bentuk nilai nominal uang, tetapi bentuk keikhlasan, kasih dan kesatuan hati (fa'omasi/fahasara dödö) antara orang tua laki-laki dengan orang tua perempuan. Berbeda pada masa sekarang, kalau sekarang anak laki-laki dan anak perempuanlah yang akan menentukan siapa yang akan menjadi pendamping hidupnya, bukan lagi orang tua seperti yang dilakukan pada masa dahulu. Sehingga dari hal ini orang tua tidak lagi mendasarkan kasih dalam menentukan jujuran atau böwö tetapi berdasar dari pendidikan perempuan.

Pada masa dahulu bukan anak laki-laki dan perempuan yang menentukan pasangannya; yang menentukan ialah orang tua anak laki-laki dan perempuan yang sudah terlebih dahulu menjalin hubungan kekeluargaan dan memiliki kasih dan kesatuan hati. Penerapan kasih inilah yang menjadi dasar sebenarnya untuk menjalin 
hubungan kekeluargaan kedua pihak (famakhai zitenga bö'ö), sehingga böwö yang akan diberikan disesuaikan dengan kemampuan pihak keluarga laki-laki.

Pada saat ini böwö telah bergeser menjadi kata gogoila (ketentuan) karena dalam menentukan böwö tidak didasarkan kasih seperti yang dilakukan oleh orang tua pada masa dulu. Orang tua pada saat ini meminta nilai nominal böwö yang sangat tinggi karena anak mereka sudah disekolahkan. Sebagai konsekuensinya orang tua meminta nilai nominal böwö yang tinggi kepada orang tua laki-laki, belum lagi jumlah undangan dan memperkirakan siapa saja yang hendak di fosumange. Etimologi böwö adalah hadiah, yakni pemberian yang cumacuma sehingga arti sejati böwö mengandung dimensi aktualisasi kasih sayang orang tua terhadap anaknya dan bukti perhatian orang tua terhadap anaknya. ${ }^{20}$

Dalam adat Nias, böwö merupakan fasumangeta (penghormatan) kepada seseorang yang tidak melakukan perbuatan baik tanpa ada imbalan jasa. Namun dalam prakteknya secara khusus dalam adat istiadat pernikahan, böwö menjadi beli niha (harga orang). Dikatakan demikian, karena dalam proses pelaksanaannya lebih menentukan adalah jumlah böwö yang harus dibayar. ${ }^{21}$

Orang tua yang sudah menikahkan anaknya, mengatakan bahwa böwö itu memang pada awalnya adalah cinta kasih. Namun, meskipun orang tua ingin menerapkan kasih kepada anak-anaknya kalau mereka tidak memiliki harta untuk diberikan kepada anakanaknya Ketika dinikahkan, orang tua meminta nilai nominal böwö yang tinggi untuk memenuhi kebutuhan si anak pada acara pesta. Orang tua mengatakan bahwa böwö yang diminta itu dipergunakan untuk kebutuhkan pada saat pesta pernikahan dilangsungkan (soguna bazima'ö-ma'ökhö) [Waruwu, Hia \& Gulo, Wawancara, 27-29/4].

20 Nursayani Maru'ao, “Analisis Penyebab Menurunnya Penerapan Fangowai Dan Fame'e Afo Dalam Pesta Adat Perkawinan Di Kecamatan Lotu Kabupaten Nias Utara: Kajian Sosiolinguistik" (Universitas Muslim Nusantara Al Washliyah, 2014), 89.

21 Yuniman Tafonao, "Persepsi Masyarakat Nias Terhadap Film Lua-Lua Mbowo Sebua" (Medan Area, 2018), 41-42.
Pihak lain juga berpendapat bahwa böwö sebenarnya jujuran yang sudah disepakati tokoh adat pada masa dulu. Böwö pada saat ini sudah membuat orang-orang yang berasal dari kampung atau daerah sekitar enggan mencari pasangan di Desa Sisarahili-I karena nilai nominal böwö yang tinggi. Generasi muda di desa ini sebenarnya tidak setuju dengan nilai nominal böwö yang tinggi, namun mereka juga tidak bisa memaksakan orangtua untuk menurunkan atau menyederhanakannya karena status mereka sebagai anak harus patuh terhadap perintah orang tua. Jika mereka meminta agar böwö diturunkan, maka mereka akan menjadi bahan pembicaraan masyarakat karena sudah berani meminta hal itu kepada orang tua. Oleh karena itu, mereka dengan terpaksa harus mengikuti apa saja yang dikatakan orang tua. Generasi muda mengharapkan supaya nilai nominal böwö dapat disederhanakan sesuai dengan kemampuan pihak laki-laki [Wawancara, 4/5].

Sesuai dengan penelitian lapangan yang sudah dilakukan, ditemukan ada sekitar 20 orang perempuan berusia paruh baya ke atas belum menikah, 30 orang yang menikah di luar Nias, dan 10 orang yang kawin lari.

\section{PEMBAHASAN}

Sesuai dengan hasil penelitian lapangan yang dilakukan maka dapat dikatakan bahwa böwö wangowalu perlu ditransformasi karena arti dan maknanya telah bergeser akibat perubahanperubahan sosial. Asumsi ini bertolak belakang dengan hasil pengamatan sebelumnya, bahwa böwö wangowalu haruslah disederhakankan. Nilai nominal böwö yang diminta perlu disesuaikan dengan tingkat kedudukan adat orang tua, dan bukan karena factor pendidikan anak. Jika anak berpendidikan tinggi dan memiliki pekerjaan tetap, maka nilai nominal böwö yang diminta akan tinggi juga, walaupun tingkat kedudukan orang tua dalam adat hanya masyarakat biasa.

Warga desa Sisarahili-I yang sudah diwawancarai mengatakan bahwa penentuan böwö sudah tidak lagi berpatokan pada aturan yang sudah diputuskan oleh para tokoh adat pada zaman dahulu. Hal ini, terjadi karena para orang tua sudah tidak lagi memperhatikan aturan yang ada. Bagi orang tua aturan itu 
hanya berlaku pada zaman dahulu dan mereka juga mengatakan bahwa jika aturan-aturan itu dilaksanakan maka akan memakan waktu yang sangat lama dan juga terlalu sulit untuk disebut satu-persatu itu. Itulah alasan-alasan yang akan diberikan jika ditanyakan kepada orang tua, pada hal mereka sebenarnya tidak tahu bahwa dengan hal itu mereka sudah menghilangkan adat yang sudah ada dan memberatkan pihak laki-laki dalam menyerahkan jujuran pernikahan.

Ada beberapa perubahan-perubahan wujud böwö wangowalu yaitu: dahulu kala perkawinan seorang laki-laki di Nias didasarkan pada jumlah kepala yang dia penggal. Bila ia dapat membawa lima kepala, maka ia dapat mengawini perempuan sebanyak itu. Ini menunjukkan keperkasaan dan kepandaian. Kemudian sebelum Ono Niha mengenal emas dan perak, böwö dinyatakan dalam bentuk kerja (ono yomo), ngaso'e wakhe (takaran beras), dan rozi mbawi (unit/kilo daging babi) yang ditakar dengan afore serta saga (takaran babi).

Sejak Ono Niha mengadakan barter dengan pihak luar (Baros, Johor, Aceh, Minang), dan mengenal emas, maka selain ngaso'e wakhe dan bawi, juga menggunakan emas, dengan ungkapan köla, batu (emas), aya (aya nina, aya gawe, aya zalawa, dsb). Semenjak Belanda masuk Indonesia, termasuk Nias dan memperkenalkan mata uang gulden atau di Nias dikenal dengan istilah firö, maka inipun termasuk dalam unsur böwö walowa. Setelah Indonesia merdeka dan memiliki mata uang rupiah, hingga sekarang, umumnya yang dipakai untuk menyatakan böwö walowa adalah: (1) uang rupiah, (2) babi, dan (3) beras. Walaupun di bagian selatan Nias masih menggunakan takaran batu (emas), namun selalu saja diuangkan dalam mata uang rupiah.

Upaya pembaharuan juga sudah dari dulu dilakukan oleh para misionaris yang datang ke Nias. Upaya yang mereka lakukan adalah mengumpulkan para salawa untuk menyusun keputusan Residen yang membahas tentang böwö wangowalu. Pembahasan ini berlanjut hingga pada persidangan sinode BNKP dengan tujuan agar böwö wangowalu dapat disederhanakan sesuai dengan yang diharapkan. Walau demikian, upaya yang dilakukan oleh para misionaris itu tidak ditindaklajuti oleh orang Nias.
Memahami pesta perkawinan di Nias hendaknya dipahami dari format sosial masyarakat. Stratifikasi yang dibagi atas bangsawan, kaum kebanyakan dan budak. Setiap kelas memiliki kharakter sosial, ekonomi, keberagamaan. Juga berbeda soal derajat kuasa dalam pengambilan keputusan di tengah masyarakat. Penting menelusuri nilai dari stratifikasi sosial yang ada di Nias, sebab perkawinan merupakan salah satu acara dalam perobahan status sosial seseorang di tengah masyarakat. Dahulu perkawinan terlaksana bagi yang sama bosi-nya. Nilai material böwö-pun cukup tinggi. Ini tidaklah persoalan, sebab pihak yang datang (tome) adalah juga dari bosi yang tinggi, yang notabene adalah berkeadaan dan bahkan merupakan kebanggaan bila dapat memberi lebih besar.

Kritik sosial pada tingginya böwö juga terlihat dari syair dan lirik lagu Nias. Jika diperhatikan ada banyak lirik lagu dan juga syair maena yang diciptakan akibat dari tingginya nilai böwö. Misalnya "habörö wa'atabö mbawimi, habörö wa'ebua gana'ami wamifabali zalukhö faröi ba mifaröi zalukhö fabali." Seringkali orang tua juga menganggap bahwa dengan meminta nilai nominal böwö yang tinggi akan merasa diri hebat sehingga lirik maena ini menggambarkan bahwa karena harta yang berlimpah kalian memisahkan perempuan dengan saudara dan saudarinya yang lain. Jika dilandaskan dengan kasih, maka syair maena tersebut dapat diubah menjadi habörö wahasara dödömi habörö böwö fa'omasimi wamifabali zalukhö faröi ba mifaröi zalukhö fabali. Begitu juga dengan lirik lagu yang dinyanyikan oleh Ella Daeli yang berjudul "Lua-lua Mböwö Sebua." Syair dan lirik ini hendak memberitahukan kepada orang banyak termasuk orang tua bahwa meminta böwö dengan nilai niominal yang sangat tinggi akan membuat keluarga yang baru dibentuk akan sengsara dan menderita. Alhasil, semua perhiasan yang diberikan kepadanya akan dijual untuk melunasi semua utang-utang pesta pernikahan mereka.

Jika dianalisis dari hoho yang mengatakan amuata si sökhi bua-bua fa'omasi tenga nisu'a ba lahe gana'a tenga nifaedogö ba mbawi olola no böwö masimasi amuata sogaena ba zi sandohu fa'auri fekoli ba gölia yang artinya bahwa böwö itu bukan karena emas dan uang yang banyak tetapi karena dilandasi kasih yang dari hati akan tetapi saat 
ini orang terkadang memandang böwö itu sebagai harga yang akan dibayarkan kepada orang tua perempuan. Adat sudah tidak lagi berfungsi, adat tidak dimaknai secara tepat dalam kehidupan setiap orang Nias. Orang tua meminta nilai nominal uang yang sangat tinggi karena böwö telah dipahami sebagai uang dan tidak memikirkan bahwa permitaan böwö yang tinggi menimbulkan kemiskinan bagi keluarga.

Dahulu, dasar untuk melaksanakan pernikahan adat ialah sirih yang mempersatukan keluarga sebagai tanda bahwa mereka bukanlah orang asing yang hendak mencuri anak perempuan tersebut dan sebagai tanda persaudaraan dan juga sebagai tanda persatuan adat.

Böwö tidak memiskinkan tetapi yang membuat orang miskin ialah biaya pesta pernikahan sebab orang tua telah menyalahgunakan makna böwö yang sesungguhnya.

Böwö tidak bisa ditinggalkan karena böwö sudah menjadi bagian dalam kehidupan masyarakat dan böwö juga merupakan nama (töi) atau (lakömi). Setiap anak perempuan yang dinikahi oleh laki-laki dari kampung lain harus bisa memenuhi böwö yang akan diminta. Orang tua mengatakan bahwa anak perempuan mereka berharga (tenga nifatörö furi nonoma) karena jika anak perempuan yang dinikahi oleh laki-laki tidak dipestakan atau menikah tanpa mengikuti prosedur adat (soloi ma sabeto) maka böwö tidak akan diminta. Kalimat yang mengatakan sökhi mate moroi a'aila sering diungkapan oleh orang tua kepada anak perempuan, artinya bahwa perempuan itu berharga dan karena itu perempuan tidak mudah untuk dimiliki atau dinikahi oleh lakilaki tanpa melalui proses dan prosedur dalam adat. Setiap anak perempuan yang dinikahi harus dipestakan secara adat, disaksikan oleh warga kampung dan disahkan oleh agama dan pemerintahan. Dapat disimpulkan bahwa böwö itu harus tetap ada karena böwö memiliki nilai luhur yang tinggi dalam masyarakat.

\section{KONKLUSI}

Upaya transformasi yang dilakukan ialah untuk mendatangkan damai sejahtera. Unsur adat dalam masyarakat tidak dibuang. Sebagaimana ragi dan tepung dapat menghasilkan berbagai jenis roti dan kue, demikian pula perubahan dan pergeseran dalam masyarakat, tidak boleh meninggalkan unsur-unsur yang sudah ada. Jika berbicara soal bosi (status sosial), maka harus diperhatikan bahwa dalam masyarakat sekarang ini, sedikit sekali yang memperhatikan bosi bahkan tidak peduli lagi dengan kedudukannya. Sebab orang yang menyebut dirinya memiliki kedudukan dalam masyarakat (bosi) harus melakukan ritual-ritual sehingga akhirnya ia berada dalam kedudukan adat yang ke delapan, sembilan atau kedudukan yang kedua belas. Jika tidak melakukan ritual-ritual itu maka orang tua tidak berhak mengatakan bahwa ia memiliki kedudukan dalam masyarakat. Jika ingin melalukan transformasi maka masing-masing keluarga harus mengambil kesepakatan bersama terhadap keluarga besarnya (owuloi ngafu) dan menyepakati mengenai nilai nominal böwö. Sehingga mulai dari kesepakatan keluarga, böwö bisa disederhanakan tanpa menimbulkan masalah dalam keluarganya.

Para tokoh adat, pemerintah, aparat desa haruslah dapat menjadi contoh kepada masyarakat lainnya dengan cara mengikuti aturan yang sudah ditetapkan dalam fondrakö Moro'ö si lima ina. Gereja/pelayan dapat berperan dengan memberikan saran melalui khotbah-khotbah yang disampaikan, supaya warga jemaat mengerti dan memahami makna perkawinan yang sesungguhnya. Dalam khotbah dapat diingatkan bahwa makna böwö sesungguhnya adalah kasih yang ditunjukkan kepada anak maupun kepada orang lain tanpa mengharapkan balasan. Kehidupan para pelayan, menjadi contoh bagi warga jemaat. Pemaknaan böwö dapat didalami melalui nats-nats Alkitab.

Tokoh adat, pemerintah, para pelayan gereja, dan aparat desa dapat bekerja sama untuk mengadakan sosialisasi secara berkesinambungan mengenai böwö wangowalu kepada masyarakat dan membagikan buku mengenai fondrakö Moro'ö si lima ina dan menjelaskan kepada mereka isi fondrakö Moro'ö si lima ina terkhusus dalam topik pembahasan mengenai böwö pernikahan.

\section{REFERENSI}

Delima, Maria Grace. “Kedudukan Sinamot (Uang Jujur) Dalam Perkawinan Menurut Hukum 
Adat Batak Toba." Universitas Indonesia, 2014.

Gowasa, Fransiskus Andi Luanta. "Perkawinan Semarga Menurut Hukum Adat Nias (Studi Di Kabupaten Nias Selatan Dan Kota Gunungsitoli)." Universitas Sumatera Utara, 2019.

Gulo, W., ed. "Injil Dan Budaya Nias." In Seminar Lokakarya Perjumpaan Injil Dan Budaya Nias. Gunungsitoli: Panitia Semiloka, 2004.

Maru'ao, Nursayani. "Analisis Penyebab Menurunnya Penerapan Fangowai Dan Fame'e Afo Dalam Pesta Adat Perkawinan Di Kecamatan Lotu Kabupaten Nias Utara: Kajian Sosiolinguistik." Universitas Muslim Nusantara Al Washliyah, 2014.

Mendrofa, Samina T. Mas Kawin (Bowo) Pada Suku Bangsa Nias. Medan: USU Press, 2007.

Pontius Gulo. Böwö Dalam Perkawinan Adat Öri Moro'ö Nias Barat. Bandung: Unpar Press, 2015.

Sidauruk, Jinner, and Lenny Verawaty Siregar. Peranan Mahar (Bowo) Dalam Tatacara Melangsungkan Perkawinan Menurut Hukum Adat Nias. Medan, 2011.

Tafonao, Petrus Meiman Syukur. "Pergeseran Penetapan Bowo Perkawinan Atas Status Sosial Di Kabupaten Nias Barat." Universitas Sumatera Utara, 2016. https://repositori.usu.ac.id/handle/1234567 $89 / 9746$.

Telaumbanua, Tuhoni. Upacara Dan Böwö Wangowalu Ba Nono Niha, Perlu Reformasi? Gunungsitoli, 2020.

Telaumbanua, Tuhoni, and Uwe Hummel. Salib Dan Adu: Studi Sejarah Dan Sosial-Budaya Tentang Perjumpaan Kekristenan Dan Kebudayaan Asli Di Nias Dan Pulau-Pulau Batu Indonesia (1865-1965). Jakarta: BPK Gunung Mulia, 2015.

Wulan, Dwi Condro. "Pandangan Hukum Islam Terhadap Tradisi Jujuran Dalam Prosesi Perkawinan Adat Banjar Di Kelurahan Sungai Malang Kecamatan Amuntai Tengah Kabupaten Hulu Sungai Utara." Universitas Islam Indonesia Yogyakarta, 2018.

Yuniman Tafonao. "Persepsi Masyarakat Nias Terhadap Film Lua-Lua Mbowo Sebua." Medan Area, 2018.

Zebua, H. S. Kamus Sederhana Bahasa Daerah Nias Indonesia. Gunungsitoli, Nias, 1996. 